\title{
INTERDisCiPlinary CAPSTONE DESIGN STREAM AT THE UNiVERSity OF WATERLOO: IMPLEMENTATION Plan
}

\author{
Cheryl Pearce ${ }^{I}$, Steve Lambert ${ }^{1}$, and. Wayne Parker ${ }^{2}$ \\ ${ }^{1}$ Waterloo Cases in Design Engineering, University of Waterloo, ${ }^{2}$ Associate Dean, Cooperative Education and \\ Professional Affairs, University of Waterloo \\ cheryl.pearce@uwaterloo.ca, steve@uwaterloo.ca,wjparker@uwaterloo.ca
}

\begin{abstract}
An interdisciplinary design approach is a collaborative effort involving team members from different engineering disciplines to solve a problem. An opportunity for interdisciplinary education exists in the fourth year capstone design project. Interdisciplinary capstone courses are offered at other Canadian universities but, at the University of Waterloo $(U W)$ the co-operative undergraduate engineering program poses a logistical barrier to students interacting with students in other disciplines for capstone design projects. Currently, students can form their own interdisciplinary team but differences in course structure, project deliverables, and design terminology and method between engineering disciplines is challenging for students and instructors. An investigation into the feasibility of a new interdisciplinary capstone design course at $U W$ is undertaken. A possible home for the interdisciplinary capstone course could be under the Chair of Design Engineering. Overall, receptivity among departments is positive but a more comprehensive analysis is required.
\end{abstract}

Keywords: Interdisciplinary Design, Multidisciplinary Design, Design Education

\section{INTRODUCTION}

There is a need for graduate engineers with an ability to work effectively in a multidisciplinary environment to deal with the complexity of today's engineering challenges. This is often difficult since there is such a strong disciplinary focus at most engineering schools. An opportunity for interdisciplinary education exists in the fourth year capstone design project. Ideally, for an interdisciplinary capstone design project to succeed, each student has to tackle concepts from their own discipline and complete the project by collaborating with students from other engineering disciplines, thereby individually meeting capstone project requirements.

A distinction between multi and interdisciplinary collaboration is as follows. In a multidisciplinary approach there is a limited exchange of information among collaborators from multiple disciplines and each collaborator brings their expertise to a problem through division of labour. An interdisciplinary approach is when persons from different disciplines work collaboratively and are integrated to combine their knowledge to solve a problem [1].

An informal inquiry of individual Departments' receptivity for a common design stream has been undertaken. Engineering programs at UW are being refined and evaluated to meet the new requirements of the Canadian Engineering Accreditation Board (CEAB) outcomes-based assessment. The CEAB graduate attributes include design as well as individual and team work: students should graduate with the ability to work effectively as a member and leader in teams, preferably in a multidisciplinary setting. An interdisciplinary capstone design course would help to both develop and meet these attributes.

The Chair in Design Engineering at UW aims to build design skills using a strong foundation of real-world experience, based on the pervasive use of engineering design cases throughout the curriculum. The Waterloo Cases in Design Engineering (WCDE) group was formed to achieve this aim. They develop cases from various sources, including from our own students' co-op work term experience, which is inherently multidisciplinary. Their use throughout the curriculum should build awareness and appreciation for the way different disciplines complement each other, and help develop fundamental design skills [2]. This would naturally be complemented by an interdisciplinary capstone project.

\subsection{Literature Review}

Interdisciplinary and multidisciplinary capstone design streams have been implemented at other universities. The following literature review focuses on Canadian engineering programs.

At Queen's University, a Multidisciplinary Design Stream (MDS) in fourth year has student teams from 
multiple disciplines collaborate and find an innovative solution for an industry based design project [3]. The MDS's initial offering was structured over three terms and students carried out the design project in the second and third terms. For the MDS projects, students are given a selection of industry based design projects and are grouped in teams based on their project choice. The MDS was open to all ten disciplines at Queens in 2005 [3].

At the University of Calgary, an interdisciplinary capstone design course was offered to Electrical, Computer, Mechanical, and Manufacturing Engineering fourth year students in 2004 [4]. Design projects were chosen so each discipline would have an equal contribution. Students in this case found the interdisciplinary capstone course useful in preparing them to join the workforce.

At the University of British Columbia, an interdisciplinary capstone course was launched in 2009. The two term course sequence has teams of fourth year students from 2-3 engineering disciplines work on design projects with an industry partner. Industry projects are solicited and students are matched with students from different departments to form project teams [5].

Overall, issues encountered from previous course implementations include logistical challenges to schedule classes to accommodate students from multiple engineering programs. Also, there is a tendency towards industry-sponsored projects for interdisciplinary design projects, solicited by course instructors. A challenge observed in previous implementations was gaining departmental approval to allow an interdisciplinary design project to be an acceptable alternative for the programbased capstone design course.

\subsection{Waterloo Context}

A capstone design course is offered in the final year of study for the 12 engineering programs at UW. In the majority of programs the capstone design project is a two course sequence. Students work in a team to solve an open-ended design problem and some students would like to work on a team with members from different engineering programs. However, project teams spanning multiple programs are limited because of logistics, and issues with assessment and meeting course requirements. Currently, students wishing to work on an interdisciplinary project enroll in their respective capstone courses for their own program and their project must meet the deliverables for their program's capstone course. The structure of this offering can be a deterrent to students since it may mean they have to meet course objectives independently if the rest of their team members are from a different engineering program.
A part of the strategic plan for the University of Waterloo's Faculty of Engineering (Vision 2015) is a proposal to create an interdisciplinary capstone course to facilitate students from multiple departments working together. A committee was tasked to develop the requirements for such a course. The Interdisciplinary Project Group (IPG) developed a draft outline, calendar entry, and proposed course delivery.

Waterloo has an added complexity in that students may be on different work/study terms due to co-op. At UW, students have the first term of fourth year (4A) in either the spring or fall term, and all students have the second term of fourth year (4B) in the winter. The sequence of $4 \mathrm{~A}$ and $4 \mathrm{~B}$ depends on program and program stream as shown in Table 1. Obviously, students must team up with students who share their course sequence in fourth year.

This teaming up may be further complicated since students in some programs switch streams immediately prior to fourth year, and so may not be on campus at the same time to meet potential teammates at the end of their third year.

Table 1: UW programs' fourth year sequence.

\begin{tabular}{|l|c|c|c|}
\hline Engineering Program & $\begin{array}{c}\text { 4A } \\
\text { Spring }\end{array}$ & $\begin{array}{c}\text { 4A } \\
\text { Fall }\end{array}$ & $\begin{array}{c}\text { 4B } \\
\text { Winter }\end{array}$ \\
\hline Chemical (4 stream) & & $\times$ & $\times$ \\
\hline Chemical (8 stream) & $\times$ & & $\times$ \\
\hline Civil & $\times$ & & $\times$ \\
\hline Electrical and Computer & $\times$ & & $\times$ \\
\hline Environmental & & $\times$ & $\times$ \\
\hline Geological & & $\times$ & $\times$ \\
\hline Management & $\times$ & & $\times$ \\
\hline Mechanical (4 stream) & & $\times$ & $\times$ \\
\hline Mechanical (8 stream) & $\times$ & & $\times$ \\
\hline Mechatronics & & $\times$ & $\times$ \\
\hline Nanotechnology & & $\times$ & $\times$ \\
\hline Systems Design & & $\times$ & $\times$ \\
\hline Software & $\times$ & & $\times$ \\
\hline
\end{tabular}

UW has a strong history of participation in student design competitions. Examples include the UW Alternative Fuels Team (UWAFT), Baja SAE, Clean Snowmobile, Formula Hybrid, Formula Motorsports, Concrete Toboggan, and the UW Midnight Sun Solar Car. These projects are inherently interdisciplinary, and hence are a strong model for any potential interdisciplinary design course. However, much of the student involvement is voluntary and takes place prior to fourth year. Students participating in these teams can often take advantage of their disciplinary capstone courses to gain credit for work on the team. Any proposed course should consider this and attempt to maximize the benefits of working on student design teams. 
The University of Waterloo has 12 Engineering programs as shown in Table 1 . While architecture is administratively connected to the Faculty of Engineering, the program is significantly different. They do not follow either of the fourth year sequences shown in Table 1. Architecture students complete their 4A term in Rome, Italy in the fall and their $4 \mathrm{~B}$ term in the spring, making collaboration on fourth year capstone projects difficult. Extracurricular participation on student teams is still possible, such as the North House (http://www.teamnorth.com/) and the Hydrogen Student Design Contest (http://www.hydrogencontest.org/).

\subsection{Motivation}

A key motivator for development of the interdisciplinary course sequence is to enhance student experience. It is believed that students would benefit from involvement with multiple disciplines for a capstone project; offering the proposed course sequence would make it easier for students to work together on these projects.

At the same time, the new Canadian Engineering Accreditation Board (CEAB) accreditation procedure focuses on graduate attributes [6]; Table 2 shows these graduate attributes. Compared to historical practices, there is increased emphasis on the non-technical aspects of engineering education. Institutions must demonstrate that graduates possess the graduate attributes and that there be a process by which they are assessed for the purposes of continuous program improvement. From Table 2 it can be seen that there is no explicit requirement to work in multidisciplinary teams in the attributes. However, as part of the individual and teamwork attribute there is mention that students graduate with the ability to work effectively as a member and leader in teams, preferably in a multidisciplinary setting [6]. ABET accredits the post-secondary engineering programs in the United States. Explicitly included in the ABET required student outcomes is a demonstrated ability to function on multidisciplinary team [7].

Table 2: CEAB graduate attributes [6].

\begin{tabular}{|l|l|}
\hline \multicolumn{1}{|c|}{ Criteria } \\
\hline 1 & A knowledge base for engineering \\
\hline 2 & Problem Analysis \\
\hline 3 & Investigation \\
\hline 4 & Design \\
\hline 5 & Use of Engineering Tools \\
\hline 6 & Individual and team work \\
\hline 7 & Communication Skills \\
\hline 8 & Professionalism \\
\hline 9 & $\begin{array}{l}\text { Impact of engineering on society and the } \\
\text { environment }\end{array}$ \\
\hline
\end{tabular}

\begin{tabular}{|l|l|}
\hline 10 & Ethics and equity \\
\hline 11 & Economics and Project Management \\
\hline 12 & Life-Long Learning \\
\hline
\end{tabular}

Feedback from industry found a need for graduating students to work effectively in multidisciplinary teams upon graduation. In 2006, May and Strong [8] surveyed alumni of Queen's University of Applied Science. The respondents were from a diverse industry background and differing responsibility levels. Industry representatives were asked to identify weaknesses in Canadian undergraduate engineering programs; no multi or interdisciplinary experience was identified as a weakness. They identified the need for Canadian engineering programs to provide opportunities for students to work and learn in multi or interdisciplinary teams, whilst maintaining the flexibility to work within their own discipline.

In 2007, an extensive survey by Engineers Canada [9], pointed out a need to enhance development of professional skills for recent engineering graduates $(0-5$ years). Professional skills viewed as essential by half of survey sample were general communication skills, interpersonal skills, and team-working skills. An interdisciplinary design course would address development of these professional skills.

The WCDE group at UW has an Industrial Advisory Committee (IAC) that provides feedback regarding the program and current industry needs for engineering design education. Senior engineers from engineering consulting and technology companies provided feedback regarding a fourth year interdisciplinary capstone design stream. Overall feedback was positive and industry partners were supportive of providing multidisciplinary industry based projects. The collected feedback falls into several themes:

- There is significant mentoring required for new graduates: explaining what different disciplines do and how to interact collaboratively and communicate with one another.

- Exposing students in fourth year studies to working with other teams and disciplines could aid the transition to the work environment.

- An underdeveloped skill of new graduates is an ability to communicate effectively using a common language with their peers.

\section{PROPOSED SOLUTION}

At the University of Waterloo, a mechanism already exists for cross-disciplinary engineering courses. These General Engineering (GENE) courses are used primarily for exchange students and courses that are offered to multiple engineering programs. Currently, GENE 401 and 402 are used to enroll exchange students in capstone 
design. The course codes GENE 403 and 404 were selected for an interdisciplinary capstone design. Table 3 is an overview of the proposed course delivery sequence for an interdisciplinary capstone course sequence at UW.

Table 3: Proposed course delivery sequence.

\begin{tabular}{|l|l|}
\hline \multicolumn{1}{|c|}{ Term } & \multicolumn{1}{c|}{ Course Activity } \\
\hline Third Year & Introduction Session(s) \\
\hline 4A (Spring and Fall) & GENE 403 \\
\hline 4B (Winter) & GENE 404 \\
\hline
\end{tabular}

For the capstone course to be successful, a single course coordinator needs to be responsible on an ongoing basis. This will likely be tied to the Waterloo Chair in Design Engineering, since they already have a crossdepartmental responsibility for design and have experience administering industry design projects as part of their MEng Design Certificate program in mechanical engineering. The responsibilities of the course coordinator would include: instruct teams regarding course requirements, schedule course deliverables, work with technical consultants for teams, assign grades, and promote the course sequence to students. Technical consultants (as necessary) would come from the various programs and would advise students that are participating in an interdisciplinary design team.

Introductory sessions must provide information to students, and give them sufficient time to consider this option, identify potential teammates, and gain appropriate approvals from their departments, as appropriate. It is anticipated that students would have the option of proposing their own project, either based on a previous co-op work term experience or an entrepreneurial idea, or to choosing from suggested industry projects solicited by the course coordinator.

It will be necessary to hold two sessions for GENE 403 in both the spring and fall terms; students will enroll according to their stream, Table 1. The IPG committee has drafted proposed calendar entries for the two new courses, Appendix A. The focus of the first course is defining (or finding) the problem and identifying the opportunity, proposing potential solutions and selecting the best solution. The wording was chosen to reflect graduate outcomes including communication; consideration of safety, regulatory, sustainability and professional ethics requirements; teamwork and leadership; and risk and project management. The second course focuses on carrying this proposed solution to completion, including appropriate revision based on feedback, implementing and verifying the solution.

An attempt was made to make this description as general as possible to ensure maximum participation rates of programs and students, while maintaining the essential features of an effective design project. The primary logistical challenge was addressed by offering the $4 \mathrm{~A}$ course twice. However, some programs may be unable to participate since their capstone course is a three course sequence. Further work is required to determine if it is possible for students to enroll in the interdisciplinary project sequence only in 4A and 4B. Specific deliverables for each interdisciplinary project are expected to depend on the project and the course instructor will need to discuss and approve the deliverables proposed by the interdisciplinary teams. The proposed deliverables should satisfy the specified learning outcomes for the course.

\section{DISCUSSION}

Engineering institutions have responded to an increase in technological complexity by introducing programs with more specialization. The University of Waterloo has introduced the following specialized programs: Software Engineering, Mechatronics Engineering, Management Engineering, and Nanotechnology Engineering. New programs often bridge a gap between conventional disciplines, for example mechatronics engineering is a blend of mechanical and electrical engineering. An argument can be made that in some instances these specialized engineering programs are inherently interdisciplinary when compared to conventional engineering programs [2]. Graduating students from such specialized programs may be able to integrate well into a multidisciplinary work environment that is composed of disciplines drawn upon in their program of study. For example, a graduating mechatronics student may graduate with appropriate skills to work in a multidisciplinary team of electrical and mechanical engineers.

An informal inquiry of individual Departments' receptivity for a common design stream has been completed. Of interest were past interdisciplinary design projects, how they were evaluated, and student interest for interdisciplinary capstone team projects. Participants were all from UW and included IPG committee members, departmental undergraduate chairs, and faculty who instruct fourth year capstone design courses. In some cases people were familiar with the interdisciplinary capstone design proposal, and in other cases they were not. Acceptance of an interdisciplinary design project as an alternative to current disciplined based capstone courses is an important consideration. Based on informal conversations with different departments there is positive feedback to an interdisciplinary capstone course. The following summarizes some of the observations from this inquiry.

Some see the student competition teams as an ideal model for interdisciplinary design projects. The competitive environment and competition rules provide a real-world engineering context for design. This provides the motivation to excel and the constraints on time and 
budget. At the same time, the requirements are sufficiently complex to require interdisciplinary knowledge and skills. An interdisciplinary capstone course should accommodate student teams.

Student teams at UW have a shared leadership approach is this would be the ideal structure for interdisciplinary design groups. In the interdisciplinary capstone project there should be equal opportunity for all team members to grow as engineers and leaders.

While some students will have had prior experience working in a team, either on a student team or in disciplinary courses in their program, team dynamics will be more important in an interdisciplinary environment. It will be particularly important to evaluate and track team dynamics. In initial offerings it will be important to evaluate the pairings of students from multiple engineering programs to continuously improve the course delivery. Using a software system such as Comprehensive Assessment for Team-Member Effectiveness (CATME) to gather peer and self-evaluation data can aid the interdisciplinary capstone course coordinator in this evaluation [10].

Along with ensuring effective team work it will be important for the course coordinator to monitor the technical requirements of each project to ensure work for students from different disciplines is balanced, and to help ensure no disengagement of any group members. It is expected that projects will have faculty members as supervisors and it may be necessary to have additional technical consultants for some aspects of an interdisciplinary project. As a result, when a student team proposes a project topic, expected contributions of each team member must be included in the initial proposal to the course coordinator.

Currently, some programs offer significant monetary and prestige awards and industry supported grants for students. As this structure differs significantly between programs there might be more incentive for students to work in their own discipline. A similar award system should be considered for interdisciplinary capstone projects or a mechanism developed to allow for team eligibility in their "home" departments for funding and awards.

Participants from several programs expressed a need for collaboration outside of engineering. For example, the 2011 Hydrogen Student Design Contest challenged university-level students to plan and design a residential hydrogen fueling system [11]. A chemical engineering team for their $4^{\text {th }}$ year project tackled the problem and won first place in the competition in 2011. The team was interdisciplinary and benefited from having a team member from architecture. Often collaborations with other faculties are done via a faculty supervisor rather than including undergraduate students from another a faculty on a team. These projects would not fall under an interdisciplinary capstone project, which requires a mix of students from multiple engineering programs.

As the interdisciplinary capstone course is in the initial planning stages, a pool of potential course coordinators and technical consultants from various Departments is required to advance the initiative. An initial offering will demonstrate the student interest level for the course sequence. A first offering is anticipated in Spring 2013.

Note that the intention in the above is to replace existing disciplinary capstone projects for some students. Another option is to participate in the interdisciplinary capstone course as a fourth year technical elective, in addition to a disciplinary capstone. The difficulty here is that this will displace two technical elective courses in a student's fourth year, and there may be some resistance from some programs since students will have two significant projects.

\section{CONCLUSION}

Offering an interdisciplinary capstone design course as an alternative to program specific programs is proposed at University of Waterloo. An interdisciplinary capstone course must consider course delivery, instruction, technical consultants, project deliverables, student team formation, and appropriate project topics. At UW accommodating students in co-op adds an extra complexity and results in year-round instruction for an interdisciplinary capstone course. Important considerations obtained from stakeholder feedback include the need for methods to assess student team dynamics, importance of a single course instructor/coordinator, accommodating student team and competition projects, and student prize eligibility.

\section{Acknowledgements}

The authors would like to thank the IPG committee members, undergraduate chairs, and faculty members at the University of Waterloo who took the time to consult regarding their program's capstone course and experiences. Thanks also to members of the WCDE Industrial Advisory Committee who took the time to discuss their experiences regarding multidisciplinary design in engineering consulting and technology industries.

\section{References}

[1] M. Borrego, and LK.. Newswander, "Characteristics of Successful Cross-disciplinary Engineering Education Collaborations," Journal of Engineering Education, vol. 97, no. 2, pp. 123-134, April 2008. 
[2] S. Lambert, and O. Nespoli, "Building a foundation for multidisciplinary design using case studies," in Proc. International Conference on Transforming Engineering Education: Creating Interdisciplinary Skills for Complex Global Environment, IEEE 2010, (Dublin, Ireland, 6-9 April 2010), 5 pages.

[3] D. Strong, "Towards Effective Multidisciplinary Engineering Education: The Multidisciplinary Design Stream at Queen's University," in Proc. Canadian Design Engineering Network International Conference, CDEN 2005, (Kananaskis, Alberta, 18-20 July 2005), 6 pages.

[4] P. Jazayeri, W. Rosehart, and D. Westwick, "Experiences and Proposals for Interdisciplinary Engineering Design Courses," in Proc. Canadian Design Engineering Network International Conference, CDEN 2005, (Kananaskis, Alberta, 18-20 July 2005), 5 pages.

[5] A. Hodgson, and P. Kruchten, "The UBC Chair in Design Engineering-Breaking Out of Disciplinary Silos," in Proc. Canadian Design Engineering Network International Conference, CDEN 2009, (Hamilton, Ontario, 27-29 July 2009), 6 pages.

[6] Engineers Canada, Canadian Engineering Accreditation Board, "Accreditation Criteria and Procedures 2010", Available as of April 15, 2012 from http://www.engineerscanada.ca/e/files/Accreditation_Criteri a_Procedures_2010.pdf

[7] ABET, "Criteria for Accrediting Engineering Programs, 2012-2013", Available as of May 7, 2012 from http://www.abet.org/engineering-criteria-2012-2013/

[8] E. May, and D. Strong, "Is Engineering Education Delivering What Industry Requires?," in Proc. Canadian Design Engineering Network International Conference, CDEN 2006, (Toronto, Ontario, 24-26 July 2006), 9 pages.

[9] Engineers Canada, Engineering and Technology Labour Market Study, "2007 Engineering and Technology Employer Survey", Available as of May 9, 2012 from http://www.engineerscanada.ca/etlms/media/2007\%20Empl oyer\%20Survey\%20Report.pdf
[10] M. Ohland, "CATME Team-Maker About", Available as of May 6, 2012 from

https://engineering.purdue.edu/CATME.

[11] Hydrogen Student Design Contest, 2011, "2011 Contest: Residential Fueling with Hydrogen", Available as of May 6, 2012 from http://www.hydrogencontest.org/previous.asp\#6

\section{APPENDIX A: Calendar Entry}

\section{GENE 403: Interdisciplinary Design Project 1}

This is the first course in a 2-course sequence where students from more than one engineering program work together to solve an engineering problem. In the course they will formulate and communicate an engineering problem or opportunity; develop a feasible design project proposal and plan; generate feasible solutions that address the formulated problem; address safety, regulatory, sustainability and professional ethics requirements, as appropriate; effectively manage design project technical and non-technical risks using project management tools and techniques; work effectively as a team member and/or team leader.

GENE 404: Interdisciplinary Design Project 2 This is the second course in a 2-course sequence where students from more than one engineering program work together to solve an engineering problem. At the end of this course students will be able to re-formulate and recommunicate an engineering problem or opportunity (as appropriate); revise and communicate a feasible design project plan; revise solutions that address the formulated problem (as appropriate); implement and verify design solutions by analysis and/or test; communicate design solutions using accepted data formats and working documents; address safety, regulatory, sustainability and professional ethics requirements, as appropriate; effectively manage and communicate design project plans, technical and nontechnical risks, using project management tools and techniques; work effectively as a team member and/or team leader 